\title{
Effects of water and fluorine on the viscosity of albite melt at high pressure: a preliminary investigation
}

\author{
Donald B. Dingwell and Bjørn O. Mysen \\ Geophysical Laboratory, Carnegte Institution of Washington, Washington. DC 20K)(IB (L.S.A.)
}

Received February 12, 1985; revised version received April 3, 1985

\begin{abstract}
The viscosities of fluorine- and water-bearing melts based on albite composition have been determined at 7.5. 15 and $22.5 \mathrm{kbar}$ by the falling-sphere method. All melt viscosities decrease isothermally with increasing pressure. At $1200^{\circ} \mathrm{C}$ the viscosity of the fluorine-bearing melt (albite +5.8 wit fluorine substituted for oxygen, denoted $A b F_{2} O$, decreases from $5000 \pm 750 \mathrm{P}$ at $7.5 \mathrm{khar}$ to $1600 \pm 240 \mathrm{P}$ at $22.5 \mathrm{kbar}$. At $1400^{\circ} \mathrm{C}$ the viscosity of this melt decreases from $1300 \pm 200 \mathrm{P}$ at $7.5 \mathrm{kbar}$ to $430 \pm 65 \mathrm{P}$ at $22.5 \mathrm{kbar}$. At $1400^{\circ} \mathrm{C}$ the viscosity of albite +2.79 wt. $\%$ water (denoted $\mathrm{AbH}_{2} \mathrm{O}$ ) decreases from $650 \pm 100 \mathrm{P}$ at $7.5 \mathrm{kbar}$ to $400+60 \mathrm{P}$ at $22.5 \mathrm{kbar}$. Fluorine $\left(\mathrm{as} \mathrm{F}_{2} \mathrm{O}_{-}\right)$and water strongly decrease the viscosity of albite melt over the entire range of investigated pressures. The ratio of the effects of 5.8 wi. \% fluorine $[\mathrm{F} /(\mathrm{F}+\mathrm{O})$ molar $=0.10]$ and 2.79 wt. $\%$ water $[\mathrm{OH} /(\mathrm{OH}+\mathrm{O})$ molar $=0.10]$ on the $\log$ of melt viscosity $\left[د \log \eta\left(\mathrm{AbF}_{2} \mathrm{O}_{.1}\right) / د \log \eta\left(\mathrm{AbH}_{2} \mathrm{O}\right)\right]$ equals $0.90 \pm 0.05 .0 .84 \pm 0.05$ and $0.97+0.05$ at 7.5 . 15 and $22.5 \mathrm{kbar}$. respectively.

Comparison with available data on the high-pressure viscosity of albite melt indicates that both $F_{2} \mathrm{O}$, and $\mathrm{H}_{2} \mathrm{O}$ maintain their viscosity-reducing roles to lower crustal pressures. The difference between the viscosities of melts of albite, $\mathrm{AbF}_{2} \mathrm{O}$, and $\mathrm{AbH} \mathrm{O}_{2} \mathrm{O}$, may be explained in terms of the relatively depolymerized structures of $\mathrm{AbF}_{2} \mathrm{O}$, and $\mathrm{AbH}_{2} \mathrm{O}$ melts. The depolymerization of albite melt by the addition of water results from the formation of $\mathrm{Si}-\mathrm{OH}$ bonds. The depolymerization of albite melt by $\mathrm{F}_{2} \mathrm{O}$. , substitution results from the formation of non-bridging oxygens associated with network-modifying aluminum cations that are formed upon fluorine solution.

The strong viscosity-reducing effects of water and fluorine in albite melt at pressures corresponding to the mid- (s) lower continental crust indicate that these two components will strongly influence the dynamic behavior of anatectic melts during initial magma coalescence and restite-melt segregation.
\end{abstract}

\section{Introduction}

Viscosity is a fundamental property that influences the dynamic behavior of silicate melts [1-3], and dynamic processes such as melt segregation, magma mixing, crystal fractionation and fluid exsolution contribute to the compositional diversity of igneous rocks observed at the earth's surface. In addition, owing to the large compositional dependence of viscosity in silicate-melt systems, this property has been used as a tool for the investigation of melt structure in certain systems [4,5].

The pressure dependence of the viscosity of various silicate melts varies strongly with chemical composition [6-8]. Depolymerized melts such as those of diopside and sodium metasilicate composition experience a viscosity increase with in- creasing pressure [6], whereas more polymerized melts such as those of albite and jadeite composition show a decrease in viscosity with increasing pressure [7,8]. The magnitude of pressure dependence also depends on melt composition, although the data available are insufficient for generalization of the pressure dependence of silicate melts.

Two chemical components that drastically alter silicate-melt viscosities are fluorine and water [9.10]. The pressure dependence of the viscosities of water-bearing melts has received some attention [10.11], whereas the pressure dependence of the viscosities of fluorine-bearing melts has not been investigated. The viscosities of water- and fluorine-bearing melts are useful for a direct comparison of the relative depolymerizing effects of these components. With this in mind, the high- 
pressure viscosities of two melts, one fluorinebearing and one water-bearing, have been investigated. Albite was chosen as the base composition for this study because its high-pressure viscosity is known [7], the structure and properties of albite melt have been studied by several workers $[4,12-14]$ and albite is an important component of many fluorine- and water-rich igneous rocks.

\section{Experimental methods}

The viscosities of the melts were determined with the falling-sphere method. Starting materials for the viscometry experiments were water-bearing (2.79 wt. \% $\mathrm{H}_{2} \mathrm{O}$ ) and fluorine-bearing (5.8 wt.\% F) glasses. Anhydrous albite glass was made from reagent-grade $\mathrm{Na}_{2} \mathrm{CO}_{3}, \mathrm{Al}_{2} \mathrm{O}_{3}$ and $\mathrm{SiO}_{2}$. A mixture of oxides and carbonate was decarbonated at $400^{\circ} \mathrm{C}$ and fused at $1400^{\circ} \mathrm{C}$. Small. known amounts of water were added to $200-250 \mathrm{mg}$ of powdered albite glass, sealed in platinum capsules and fused in a solid-media, high-pressure apparatus at $1400^{\circ} \mathrm{C}$ for 1 hour. The resulting, water-undersaturated, albite glass was bubble-free and was used in the high-pressure viscosity measurements. The synthesis and analysis of the fluorine-bearing glass have been described previously [9]. The fluorine was added to the base composition by substituting $2 \mathrm{AlF}_{3}$ for some of the $\mathrm{Al}_{2} \mathrm{O}_{3}$. Thus the substitution is 2 moles of fluorine for one mole of oxygen, denoted by the exchange operator, $\mathrm{F}_{2} \mathrm{O}_{-1}$ (molar). The quantities of fluorine and water incorporated in the melt used in this study are equivalent in terms of the molar quantity $X /(X+$ O) where $X=\mathrm{F}, \mathrm{OH}$. The substitutions are described by the following equations:

$\mathrm{NaAlSi}{ }_{3} \mathrm{O}_{x}+x \mathrm{~F}_{2} \mathrm{O},=\mathrm{NaAlSi}_{3} \mathrm{O}_{x}, \mathrm{~F}_{2}$ 、

$\mathrm{NaAlSi}{ }_{3} \mathrm{O}_{8}+x \mathrm{H}_{2} \mathrm{O}=\mathrm{NaAlSi}{ }_{3} \mathrm{O}_{8-x} \mathrm{OH}_{2}$,

In this study $x=0.418$. This value corresponds to $X /(X+0)=0.10$. In the following discussion the water- and fluorine-bearing melts are referred to as $\mathrm{AbH}_{2} \mathrm{O}$ and $\mathrm{AbF}_{2} \mathrm{O}$. 1. respectively. These compositions are plotted in the system $\mathrm{NaAlSi}_{3} \mathrm{O}_{8}-\mathrm{F}_{2} \mathrm{O}_{-1}-\mathrm{H}_{2} \mathrm{O}$ in Fig. 1. Electron microprobe analyses of the albite and $\mathrm{AbF}_{2} \mathrm{O}$, glasses are presented in Table 1.

Platinum capsules for viscometry runs $(10 \mathrm{~mm}$

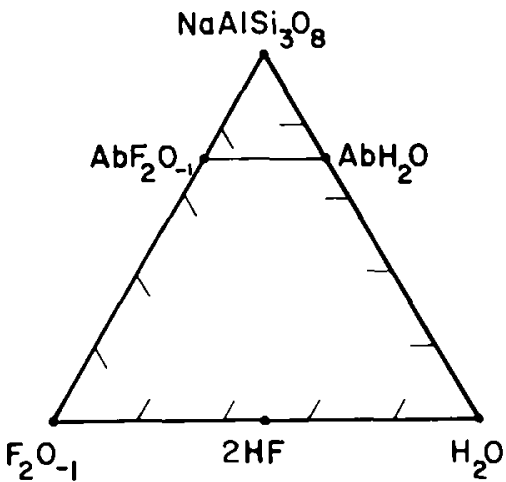

Fig. 1. Melt compositions $\mathrm{AbH}_{2} \mathrm{O}$ and $\mathrm{AbF}_{2} \mathrm{O}$, in the system $\mathrm{NaAISi}{ }_{3} \mathrm{O}_{8}-\mathrm{H}_{2} \mathrm{O} \cdot \mathrm{F}_{2} \mathrm{O}$, (in mole percent).

long. $5 \mathrm{~mm}$ diameter) were tightly packed with powdered $\mathrm{AbH}_{2} \mathrm{O}$ or $\mathrm{AbF}_{2} \mathrm{O}_{-1}$ glass, and spheres of platinum and rhodium were placed on the top of the charge. A very small amount of fine (less than $l \mu \mathrm{m}$ ) platinum powder was placed at this level to mark the starting position of the spheres. and a thin layer of powdered glass was packed above the spheres to prevent them from sticking to the capsule.

The viscometry experiments were conducted in a solid-media high-pressure apparatus by methods described previously $[8,15]$. Sealed platinum capsules were placed within $3 / 4^{\prime \prime}$-diameter furnace assemblies with tapered graphite heaters to reduce temperature gradients [8]. The temperatures were measured with a $\mathrm{Pt}-\mathrm{Pt} 10 \mathrm{Rh}$ thermocouple with no correction for the effect of pressure on electromo-

\section{TABLE: 1}

Starting compositions

\begin{tabular}{lccc}
\hline Element " & Albitc & $\mathrm{AbF}_{2} \mathrm{O}_{-}$, & $\begin{array}{l}\text { Stoichio- } \\
\text { metric } \\
\text { albite }\end{array}$ \\
\hline $\mathrm{Na}$ & 8.79 & 8.31 & 8.74 \\
$\mathrm{Al}$ & 10.36 & 9.15 & 10.29 \\
$\mathrm{Si}$ & 31.95 & 31.54 & 32.12 \\
$\mathrm{O}$ & 48.76 & 44.5 & 48.84 \\
$\mathrm{~F}$ & - & 5.8 & - \\
Total & $\overline{9} \overline{9} . \overline{86}$ & $\overline{99.30}$ & $\overline{100} \overline{00}$ \\
\hline
\end{tabular}

a $\mathrm{Na}, \mathrm{Al}$ and $\mathrm{Si}$ determined by electron microprobe: $O \mathrm{de}$ termined by stoichiometry; $F$ determined by neutron activation analysis. ( $F$ is $\pm 0.1 \mathrm{wt} . \%$ at $\mathbf{l o}$.) 
tive force. The experimental runs were raised to final run pressure plus $1520 \%$ (except at $7.5 \mathrm{kbar}$ where the runs were overpressured to $15 \mathrm{kbar}$ during initial heating) and then heated to $400^{\circ} \mathrm{C}$ below run temperature and held there for 1 minute while the pressure was trimmed to run pressure. The pressure correction for this procedure is $-3 \%$. as calibrated with the quartz-coesite transition. Finally, a rapid approach to run temperature was achieved $\left(400^{\circ} \mathrm{C} / \mathrm{min}\right)$ with an automatic controller.

A time series of three experiments was performed for each viscosity determination. The experiments ranged in duration from 4 to 200 minutes and were quenched by turning off power to the heater. This procedure resulted in quench rates of greater than $250^{\circ} \mathrm{C} / \mathrm{s}$. After an experiment, the run capsule was sawed lengthwise on two opposite sides to remove part of the platinum-capsule walls. The resulting flat plate of glass was taped to the $\mathrm{X}$-ray film holder of a flat-plate camera, and the film was exposed to Mo white radiation $(35 \mathrm{kV}, 12$ $\mathrm{mA}$ ) for 10 seconds [15]. The sphere positions were measured from the developed film with a microscope.

\section{Results}

Graphs of time vs. distance were constructed for each sphere size, and straight lines were fitted to the data (Fig. 2). These time-distance lines pass through the origin. within error. Although melt densities can be calculated from the data obtained in this study, analysis of errors resulting from propagation of the errors in sphere radii and velocities yields large density uncertainties because of the large density contrast between the melts $\left(2.53 .0 \mathrm{~g} / \mathrm{cm}^{3}\right)$ and the metal spheres $(12-21$ $\left.\mathrm{g} / \mathrm{cm}^{3}\right)$. In this study the densities of quench glasses. determined by the method of Berman [16]. were used in the calculation of melt viscosities. The melt densities are probably 10-20\% lower than the measured glass densities [8]: owing to the large density contrasts between the melt and metal spheres, however. the effect on calculated melt viscosities is insignificant. Sphere velocities, sphere radii and glass densities were used as input data for a FORTRAN program that incorporates cor-

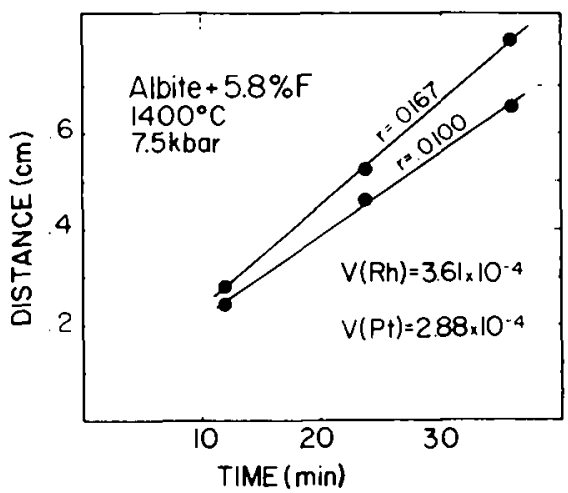

Fig. 2. Relation between time and distance of sinking of metal spheres (radii. $\pm 0.01 \mathrm{~cm}$; velocities, $\pm 5 \%$ ).

rections for metal compressibilities and thermal expansivities [17] and the Faxen correction [10] for wall effects and solves for melt viscosity. Propagation of the uncertainties in sphere position and size yields estimates of $\pm 15 \%$ for viscosity.

The glass densities, sphere sizes and sphere velocities are presented in Table 2 together with the computed melt viscosities. In Fig. 3 the data from this study are compared with data for albite melt $\left(1400^{\circ} \mathrm{C}\right)$ and 0.001 to $20 \mathrm{kbar}[4.7]$. for $\mathrm{AbF}_{2} \mathrm{O}$, melt $\left(12001400^{\circ} \mathrm{C}\right.$ and 0.001 kbar. [9]) and for low-pressure (1 2 kbar) $\mathrm{AbH}_{2} \mathrm{O}$ melt calculated by the method of Shaw $\left(1400^{\circ} \mathrm{C} .[18]\right)$.

The viscosity of the $\mathrm{AbF}_{2} \mathrm{O}$, melt decreases

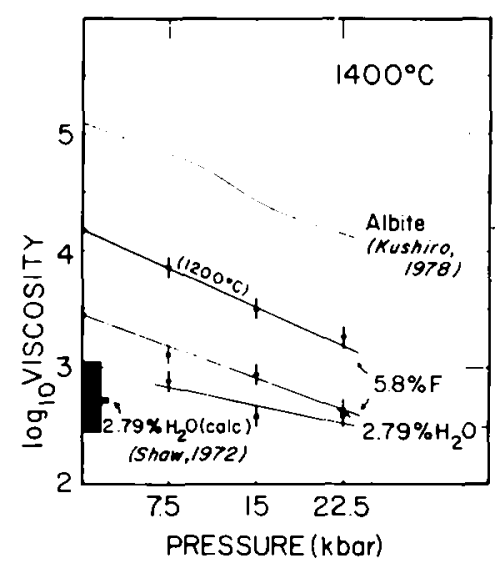

Fig. 3. Fxperimental results and comparison with data for alhite melt [4.7]: fluorine-bearing albite melt at 1 atm [9] and water-bearing alhite melt (calculated [18]). 
TABI.F: 2

Experimental conditions and results ${ }^{d}$

\begin{tabular}{|c|c|c|c|c|c|c|c|}
\hline \multirow[t]{2}{*}{ Composition } & \multirow{2}{*}{$\begin{array}{l}T \\
\left.{ }^{\circ}()^{\circ}\right)\end{array}$} & \multirow{2}{*}{$\begin{array}{l}P \\
\text { (khar) }\end{array}$} & \multirow{2}{*}{$\begin{array}{l}\text { Radius } \\
\left(\times 10^{-2}\right. \\
\mathrm{cm})\end{array}$} & \multirow{2}{*}{$\begin{array}{l}\text { Speed } \\
(\times 10 \\
\mathrm{cm} / \mathrm{s})\end{array}$} & \multirow{2}{*}{$\begin{array}{l}\rho_{\mathrm{glass}} \\
\left(\mathrm{g} / \mathrm{cm}^{3}\right)\end{array}$} & \multicolumn{2}{|c|}{ Viscosity $(\mathrm{P})$} \\
\hline & & & & & & & mean \\
\hline \multirow[t]{6}{*}{$\mathrm{AbH}_{2} \mathrm{O}$} & 1400 & 7.5 & $1.33 \mathrm{Rh}$ & 5.20 & 2.33 & 611 & 650 \\
\hline & & & $1.00 \mathrm{Pt}$ & 5.22 & & 679 & \\
\hline & & 15.0 & $1.33 \mathrm{Rh}$ & 8.00 & 2.33 & 397 & 370 \\
\hline & & & $0.87 \mathrm{Pt}$ & 6.80 & & 337 & \\
\hline & & 22.5 & $1.33 \mathrm{Rh}$ & 7.50 & 2.38 & 424 & 400 \\
\hline & & & $1.00 \mathrm{PI}$ & 9.52 & & 374 & \\
\hline \multirow[t]{12}{*}{$\mathrm{AbF}_{2} \mathrm{O}$} & 1400 & 7.5 & $1.67 \mathrm{Rh}$ & 3.61 & 2.36 & 1324 & 1300 \\
\hline & & & $1.00 \mathrm{Pt}$ & 2.88 & & 1229 & \\
\hline & & 15.0 & $1.67 \mathrm{Rh}$ & 5.35 & 2.39 & 895 & 820 \\
\hline & & & $1.00 \mathrm{Pt}$ & 4.72 & & 751 & \\
\hline & & 22.5 & $1.67 \mathrm{Rh}$ & 9.57 & 2.41 & 459 & 4.30 \\
\hline & & & $1.00 \mathrm{Pt}$ & 9.83 & & 400 & \\
\hline & 1200 & 7.5 & $1.03 \mathrm{Pt}$ & 0.68 & 2.42 & 5486 & 5000 \\
\hline & & & $1.70 \mathrm{Pt}$ & 2.07 & & 4534 & \\
\hline & & 15.0 & $1.25 \mathrm{Pt}$ & 1.96 & 2.46 & 2748 & 2900 \\
\hline & & & $1.00 \mathrm{PI}$ & 1.20 & & 2964 & \\
\hline & & 22.5 & $1.50 \mathrm{Pt}$ & 4.67 & 2.48 & 1612 & 1600 \\
\hline & & & $1.03 \mathrm{Pt}$ & 2.47 & & 1524 & \\
\hline
\end{tabular}

"Lncertainties are as follows: $T, \pm 10^{\circ} \mathrm{C} ; P,+0.5 \mathrm{kbar}$; radius, $\pm 0.001 \mathrm{~cm} ;$ speed. $\pm 5 \%: \rho_{\text {glass }} \pm 0.01 \mathrm{~g} / \mathrm{cm}^{3}:$ viscosity, $\pm 15 \%$.

with increasing pressure from 0.001 to $22.5 \mathrm{kbar}$. The decrease in viscosity is similar at $1200^{\circ} \mathrm{C}$ $(17.800 \pm 900 \mathrm{P}$ at $0.001 \mathrm{kbar}$ to $1600 \pm 240 \mathrm{P}$ at $22.5 \mathrm{kbar})$ and at $1400^{\circ} \mathrm{C}(2900 \pm 150 \mathrm{P}$ at 0.001 kbar to $430 \pm 65 \mathrm{P}$ at $22.5 \mathrm{kbar}$ ). The pressure dependence of viscosity may be fitted to an

TABLE 3

Arrhenius parameters *

\begin{tabular}{llll}
\hline Composition & $\begin{array}{l}\text { Temperature } \\
\left({ }^{\circ} \mathrm{C}\right)\end{array}$ & $\begin{array}{l}V_{\mathrm{a}} \\
\left(\mathrm{cm}^{3} / \text { mole }\right)\end{array}$ & $\log _{10} \eta_{11}$ \\
\hline $\left.\mathrm{AhH}_{2} \mathrm{O}\right)$ & 1400 & $0.45 \pm 0.35$ & $2.87 \pm 0.18$ \\
$\left.\mathrm{AbF}_{2} \mathrm{O}\right), 1$ & 1400 & $1.14 \pm 0.09$ & $3.43 \pm 0.04$ \\
& $1200)$ & $1.26 \pm 0.19$ & $4.16 \pm 0.10$ \\
\hline & Pressure & $E_{4}$ & $\log _{10} \eta_{1}$ \\
& $(\mathrm{kbar})$ & $(\mathrm{kcal} /$ mole $)$ & \\
\hline $\mathrm{AbF}_{2} \mathrm{O}, 1$ & 0.001 & 45.5 & -2.50 \\
& 7.5 & 35.2 & -1.25 \\
& 15.0 & 33.8 & -1.25 \\
& 22.5 & 33.8 & -1.70
\end{tabular}

Uncertainties quoted at $1 \sigma$.
Arrhenius equation of the form:

$\log _{10} \eta=\log _{10} \eta_{0}-V_{\mathrm{a}} P / 2.303 R T$,

where $P$ is the pressure (dyne $/ \mathrm{cm}^{2}$ ), $\log _{10} \eta_{0}$ is the pre-exponential or frequency factor, $R$ is the gas content and $V_{\mathrm{a}}$ is the activation volume $\left(\mathrm{cm}^{3} / \mathrm{mole}\right)$ for viscous flow. The calculated activation volumes (Table 3) for $\mathrm{AbF}_{2} \mathrm{O}_{-1}$ melt are $1.26 \pm 0.19$ and $1.14 \pm 0.09 \mathrm{~cm}^{3} /$ mole, at $1200^{\circ}$ and $1400^{\circ} \mathrm{C}$, respectively. The 0.001 kbar temperature dependence of the viscosity of $\mathrm{AbF}_{2} \mathrm{O}_{-1}$ melt is Arrhenian [9]. Therefore, the temperature dependence of the viscosity of this melt at 7.5, 15 and $22.5 \mathrm{kbar}$ has been calculated (Table 3 ) according to the following Arrhenius relationship:

$\log _{10} \eta=\log _{10} \eta_{0}+E_{\mathrm{a}} / 2.303 R T$,

where $T$ is the temperature $(\mathrm{K})$ and $E_{\mathrm{a}}(\mathrm{kcal} /$ mole) is the activation energy of viscous flow. The activation energy of $\mathrm{AbF}_{2} \mathrm{O}$, melt decreases from $45.5 \mathrm{kcal} / \mathrm{mole}$ at $7.5 \mathrm{kbar}$ to $33.8 \mathrm{kcal} /$ mole at $22.5 \mathrm{kbar}$.

The $\mathrm{AbH}_{2} \mathrm{O}$ melt decreases in viscosity with 


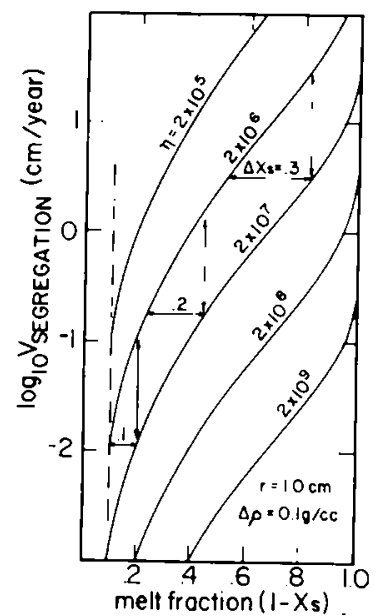

Fig. 4. The effects of melt viscosity $(\eta)$ and melt fraction $\left(1-x_{v}\right)$ on the rate of crystal-melt segregation in lower crustal granitic melts.

increasing pressure from $650 \pm 100 \mathrm{P}$ at $7.5 \mathrm{kbar}$ to $400 \pm 60 \mathrm{P}$ at $22.5 \mathrm{kbar}$ (Table 3). At $1400^{\circ} \mathrm{C}$ the high-pressure (7.5 $22.5 \mathrm{kbar})$ activation volume of the hydrous albite melt is $0.45 \pm 0.35 \mathrm{~cm}^{3} /$ mole. The viscosity of this composition, calculated from the method of Shaw (562 P. [18]), is remarkably close to the observed high-pressure range. It is not clear, however, how well the low pressure (1-2 kbar) viscosity of albite +2.79 wt. \% water would agree with this calculated value. The viscosity of the $\mathrm{AbH}_{2} \mathrm{O}$ melt is lower than the viscosity of the $\mathrm{AbF}_{2} \mathrm{O}_{-1}$ melt at all pressures. The pressure dependence of viscosity of the $\mathrm{AbH}_{2} \mathrm{O}$ melt is substantially less than that for the $\mathrm{AbF}_{2} \mathrm{O}_{-}$, melt.

The effects of $\mathrm{F}_{2} \mathrm{O}_{-1}$ and $\mathrm{H}_{2} \mathrm{O}$ on the viscosity of albite melt may be read from Fig. 3 by comparison of the data on albite melt at $1400^{\circ} \mathrm{C}$ with the results of this study at the same temperature. It is clear from Fig. 4 that $\mathrm{F}_{2} \mathrm{O}_{-1}$ and $\mathrm{H}_{2} \mathrm{O}$ both strongly decrease the viscosity of albite melt. This viscosity decrease is smaller at higher pressure. On an equimolar basis of total added $\mathrm{F}_{2} \mathrm{O}$, and $\mathrm{H}_{2} \mathrm{O}$, water has the larger effect on the viscosity of albite melt.

\section{Discussion}

\subsection{Structural implications}

It is generally accepted that albite melt has a three-dimensional network structure of intercon- nected aluminate and silicate tetrahedra [12 - 14]. with each aluminate tetrahedron stabilized by the presence of a charge-balancing sodium cation. Such a melt structure, where all oxygens form bridging bonds between pairs of tetrahedral cations, is said to be fully polymerized. The addition of any chemical components, except those that can form charge-balanced tetrahedra (e.g., $\mathrm{KAlO}_{2}, \mathrm{NaAlO}_{2}$, $\mathrm{SiO}_{2}$ ) and maintain the three-dimensional structure, will result in a disruption of the three-dimensional network structure. Thus the addition of $\mathrm{Na}{ }_{2} \mathrm{O}$ to albite melt creates a depolymerized structure in which structural units containing nonbridging oxygens are coordinated by the excess sodium. This type of depolymerization results in a decrease in melt viscosity [4].

Clearly, both the substitution of fluorine for oxygen and the addition of water result in strong decreases in melt viscosity because neither fluorine nor water can be incorporated in the structure of albite melt without disruption of oxygen bridges. The negative pressure dependence of viscosity exhibited by $\mathrm{AbH}_{2} \mathrm{O}$ and $\mathrm{AbF}_{2} \mathrm{O}$, contrasts with the positive pressure dependence of viscosity observed for (1) anhydrous depolymerized melts of diopside and sodium metasilicate composition [6], and (2) hydrous calcalkalic andesite [11]. This qualitative difference in pressure dependence may indicate that, despite their fluorine and water contents, the melts of this study remain more polymerized than the diopside, sodium metasilicate and hydrous andesite melts.

The solution of water in albite melt ruptures a number of $(\mathrm{Si}, \mathrm{Al})-\mathrm{O}(\mathrm{Si}, \mathrm{Al})$ bridges to produce $\mathrm{Si}-\mathrm{OH}$ bonds [19-21]. Estimates of the yield of $\mathrm{Si}-\mathrm{OH}$ bonds per mole of added water range from complete dissociation of added water $[19,21]$ to approximately $66 \%$ dissociation at $2.79 \mathrm{wt} \%$ added water [20]. In addition to solution of water by formation of $\mathrm{Si}-\mathrm{OH}$ bonds [19] and as molecular water [20]. Mysen et al. [21] have proposed. on the basis of spectroscopic studies, that non-bridging oxygens are formed by indirect depolymerization of the melt during the solution of water. Specifically, some of the water is associated with sodium as neutral complexes [19] that result in an excess of aluminum. which is expelled by the silicate network to form network-modifying aluminum co- 
ordinated by non-bridging oxygens (NBO) [21].

The exchange of fluorine for oxygen in albite melt must also result in elimination of some oxygen-bridging bonds. Fluorine, like water, has two possible depolymerization mechanisms. Raman spectra of fluorine-bearing silica glass [22] corroborate previous suggestions $[23,24]$ that fluorine in this melt forms $\mathrm{Si}-\mathrm{F}$ bonds. In $\mathrm{AbF}_{2} \mathrm{O}$, melt, however, it has been proposed [2S] that fluorine is associated with sodium and aluminum in the form of charge-balanced complexes. This suggestion is in agreement with previous investigations of alkali aluminosilicate melts with some fluorine substituted for oxygen [26,27]. Specifically, in albite melt, fluorine has a greater affinity for sodium than aluminum and the resulting excess of aluminum is expelled from tetrahedral coordination. This aluminum is a network modifier coordinated by non-bridging oxygens [25].

In simple systems such as albite- $\mathrm{Na}_{2} \mathrm{O}, \log \eta$ is a linear function of mole fraction $\mathrm{Na}_{2} \mathrm{O}[4,28]$ and therefore, of $\mathrm{NBO} / T$. Stolper [20, fig. 14] has implied that the decrease in $\log \eta$ of a silicate melt with added water is proportional to the concentration of $\mathrm{Si}-\mathrm{OH}$ bonds or non-bridging oxygens created in the melt. This concentration is, according to the solubility models of Burnham [19] and Stolper [20], linearly proportional to the value of NBO/ $T$ because these solubility models do not involve changes in the value of $T$. The ratio of the changes in $\log$ viscosity of albite with added fluorine and added water is $\Delta \log \eta_{\mathrm{F}} / \Delta \log \eta_{\mathrm{H}_{2} \mathrm{O}}=$ $0.90 \pm 0.05,0.84 \pm 0.05$ and $0.97 \pm 0.05$ at $7.5,15$ and 22.5 kbar, respectively. Thus, if $\log \eta$ is positively correlative with melt depolymerization $(\mathrm{NBO} / T)$ in the system albite-- $\mathrm{F}_{2} \mathrm{O}_{-1}-\mathrm{H}_{2} \mathrm{O}$, then the decreases in log viscosity lead to the inference that, at $1400^{\circ} \mathrm{C}$, the addition of $2.79 \mathrm{wt} . \%$ water to albite melt results in a more depolymerized melt structure than the substitution of $5.8 \mathrm{wt} \%$ fluorine for oxygen in albite melt.

\subsection{Geological implications}

A large number of experimental studies are available to confirm the generation of water-rich ( $>2$ wt.\%) granitic magmas within the earth's crust at pressures of 5 to 15 kbar [29-31]. In most continental areas this pressure range corresponds to mid- to lower crustal depths of $15-45 \mathrm{~km} \mathrm{[32].}$

The results in Fig. 3 indicate that the effectiveness of fluorine and water in reducing melt viscosity extends, relatively undiminished, up to pressures relevant to the anatectic formation of granitic melts. Thus, dynamic processes operating during the formation and initial coalescence of granitic melts will be influenced by the relatively low viscosities of these melts.

In particular, the extent of restite-melt segregation during anatexis and magma coalescence is important in extracting the influence of source-region inhomogeneity on the generation of chemically complex batholiths. Incomplete crystal-melt segregation, the "restite hypothesis", has been used by some workers [33-35] to explain linear trace and major element variations within intrusive suites, but has been questioned recently [36].

The important parameter in determining melt distribution in a static. partially molten source region at very low degrees of partial melting is the surface energy. It is this energy that controls whether the melt will initially pool at grain triple points or infiltrate along grain edges to form a three-dimensionally interconnected melt reservoir [37,38]. At higher degrees of partial melting, or if a shear stress is applied to the static case described above, then the magma may behave dynamically with respect to the restite material. Depending on several variables, including melt fraction, crystal size, melt-crystal density contrasts and melt viscosity, restite crystals may or may not be entrapped within the coalescing melt fraction. At degrees of partial melting sufficiently large that crystal-melt segregation may be treated as crystal settling within a less dense viscous fluid, equation (4) describes the relationship between the velocity and the viscosity of crystal-melt segregation [39]:

$$
V_{s}=2 a^{2} g \Delta \rho / 9 \eta M
$$

This equation is a modified form of Stokes' law, where $a$ is the radius of a (spherical) crystal, $g$ is gravitational acceleration, $\Delta \rho$ is the density contrast, $\eta$ is melt viscosity and $M$ is the term that accounts for the drag exerted by surrounding 
crystals [39]. * According to Arndt [39], the value of $M$ may be approximated by the following function of solid fraction $\left(X_{\mathrm{s}}\right)$ :

$$
\begin{aligned}
M= & \left(1-X_{\mathrm{s}}^{5 / 3}\right) /\left[1-(9 / 4) X_{\mathrm{s}}^{1 / 3}+(5 / 2) X_{\mathrm{s}}\right. \\
& \left.-(9 / 4) X_{\mathrm{s}}^{5 / 3}+X_{\mathrm{s}}^{2}\right]
\end{aligned}
$$

The value of $M$ ranges over several orders of magnitude, and thus the volume fraction of restite strongly influences the rate of crystal-melt segregation. Fig. 4 illustrates the functional dependence of segregation velocity on viscosity $(\eta)$ and melt fraction $\left(1-X_{s}\right)$. The efficiency of crystal-melt segregation in a coalescing magma batch depends not only on settling velocities but also on the scale and form of magma convection [3]. Therefore. in Fig. 4 it is the functional dependence of segregation velocity on melt viscosity and melt fraction. rather than the absolute magnitude of segregation velocity, that is emphasized. It is clear from Fig. 4 that a change in viscosity of an order of magnitude can shift the value of $X$, corresponding to a given crystal-melt segregation velocity by a factor that is equivalent to 10,20 or $30 \%$ of partial melting. Thus, if a critical value of crystal-melt separation velocity is necessary to achieve efficient melt segregation during partial melting [41], then the critical percentage of partial melt that can be extricated to form a distinct batch of melt will be strongly dependent on melt viscosity.

The viscosity-reducing effects of fluorine and water on silicate melts provide an explanation for certain geochemical features of water- and fluorine-rich granites and rhyolites. Firstly, there is little or no evidence for the control of major element chemistry by restite segregation in many fluorine- and water-rich granitic suites [36,42]. This behavior contrasts with geochemical trends commonly observed in water-undersaturated. fluorine-poor granitic suites. The absence of evidence

* It may be argued that if the melt fraction is very low, then the segregation of crystals from melt should be treated as the case of porous flow in a two-fluid medium [1.40]. The equations relating to such a treatment do not significantly change the conclusions regarding the dependence of segregation velocity on melt viscosity and porosity (i.e. melt frac(ion) (see [1]). dence for restite separation in water- and fluorine-rich granitic suites is consistent with early, efficient separation of crystals and melt in a magma of relatively low viscosity. Secondly, fluorine-rich granites and rhyolites are commonly enriched in several incompatible elements including $\mathrm{U}, \mathrm{Be}, \mathrm{Li}$. $\mathrm{Rb}$. Th, Nb, Sn and $\mathrm{W}[42]$. These enrichments are consistent with the derivation of fluorine-rich granites and rhyolites by unusually low degrees of partial melting of the lower crust.

\section{Summary}

The viscosities of $\mathrm{AbF}_{2} \mathrm{O}_{-1}$ and $\mathrm{AbH}_{2} \mathrm{O}$ melt decrease with increasing pressure from 7.5 to 22.5 kbar. The viscosity-reducing effects of fluorine and water on albite are not equivalent. At $1400^{\circ} \mathrm{C}$, water is more effective on a molar equivalent basis $(\mathrm{F}=\mathrm{OH})$ at concentrations of $\mathrm{F} /(\mathrm{F}+\mathrm{O})=$ $\mathrm{OH} /(\mathrm{OH}+\mathrm{O})=0.1$. The effects of water and fluorine on melt viscosity are consistent with the depolymerization of albite melt predicted from solution models for water and fluorine.

The results of this study have a direct bearing on the "restite hypothesis" of granitic magmas. It is not yet known whether fluorine and water have a significant effect on the surface energy of silicate melts, which is the major factor controlling the morphology of the partial melt fraction during low degrees of partial melting. The decrease in viscosity of albite melt with added fluorine and water, however. means that the segregation of a three-dimensionally interconnected partial melt phase from its restite will be greatly facilitated. Thus, fluorine and water may decrease the minimum degree of partial melt that can be effectively "tapped" from a lower crustal source region.

\section{Acknowledgements}

We thank G. Muncill, C.M. Scarfe, D. Virgo, H.S. Yoder, Jr. and an anonymous reviewer for their constructive comments.

\section{References}

1 F.J. Spera. Aspects of magma transport, in: Physics of Magmatic Processes, R.B. Hargraves. ed., pp. 265-323. Princeton University Press, Princeton. N.J., 1980. 
2 H.R. Shaw, Comments on viscosity, crystal settling and convection in granitic magmas. Am. J. Sci. 263, 120-153. 1965

3 R.W. Bartlett. Magma convection. temperature distribution and differentiation. Am. J. Sci. 267, 1067-1082, 1972.

4 E.F. Riebling. Structure of sodium-aluminosilicate melts containing at least 50 mole silica at $1500^{\circ} \mathrm{C}$. J. Chem. Phys. 44, 2857-2865. 1966.

5 B.O. Mysen. D. Virgo and C.M. Scarfe, Relations between the anionic structure and viscosity of silicate melts- a Raman spectroscopic approach. Am. Mineral. 65. 690710 , 1980.

6 C.M. Scarfe, B.O. Mysen and D. Virgo, Changes in viscosity and density of melts of sodium disilicate. sodium metasilicate and diopside composition with pressure. Carnegic Inst. Washington Yearb. 78. 547-551, 1979.

7 1. Kushiro. Viscosity and structural changes of albite $\left(\mathrm{NaAlSi}{ }_{3} \mathrm{O}_{8}\right)$ melt at high pressures. Earth Planet. Sci. Lett. 41. 87-90. 1978.

8 1. Kushiro. Changes in viscosity and structure of melt of $\mathrm{NaAlSi}{ }_{2} \mathrm{O}_{6}$ composition at high pressures, J. Geophys. Res. 81.6347-6350. 1976.

9 D.B. Dingwell, C.M. Scarfe and D.J. Cronin. The effect of fluorine on viscosities in the system $\mathrm{Na}_{2} \mathrm{O}-\mathrm{Al}_{2} \mathrm{O}_{3}-\mathrm{SiO}_{2}$ : implications for phonolites. trachytes and rhyolites. Am. Mineral. 70, 80-87, 1985.

10 H.R. Shaw, Obsidian- $\mathrm{H}_{2} \mathrm{O}$ viscosities at 1000 and 2000 bars in the temperature range $700^{\circ}$ to $900^{\circ} \mathrm{C}$. J. Geophys. Res. 68. 6337-6343. 1963.

11 I. Kushiro. Density and viscosity of hydrous calcalkalic magma at high pressures, Carnegie Inst. Washington Yearb. 77. 675-677, 1978 .

12 A. Navrotsky. G. Peraudeau, P. McMillan and J.-P. Coutures. A thermochemical study of glasses and crystals along the joins silica-calcium aluminate and silica-sodium aluminate, Geochim. Cosmochim. Acta 46, 2039-2047. 1982.

13 M. Taylor and G.E. Brown, Structure of mineral glasses, I. The feldspar glasses $\mathrm{NaAlSi}_{3} \mathrm{O}_{8} . \mathrm{KAISi}_{3} \mathrm{O}_{8}$ and $\mathrm{CaAl}_{2} \mathrm{Si}_{2} \mathrm{O}_{8}$, Geochim. Cosmochim. Acta, 43. 61-77, 1979.

14 F. Seifert. B.O. Mysen and D. Virgo. Three-dimensional network structure of quenched melts (glass) in the systems $\mathrm{SiO}_{2}-\mathrm{NaAlSi}_{3} \mathrm{O}_{\mathrm{x}} . \quad \mathrm{SiO}_{2}-\mathrm{CaAl}_{2} \mathrm{O}_{4}$ and $\mathrm{SiO}_{2}-\mathrm{MgAl}_{2} \mathrm{O}_{4}$. Am. Mineral. 67, 696-717, 1982.

15 R.M. Hazen and M.R. Sharpe, Radiographic determination of the positions of platinum spheres in density-viscosity studies of silicate melts, Carnegie Inst. Washington Yearb. 82, 428-430, 1983.

$16 \mathrm{H}$. Berman. A torsion microbalance for the determination of specific gravities of minerals. Am. Mineral. 24, 434-440). 1939.

17 S.P. Clark, Jr., Handbook of physical constants. Geol. Soc. Am. Mem. 97, 1966.

18 H.R. Shaw, Viscosities of magmatic silicate liquids: an empirical method of prediction, Am. J. Sci. 272. 870-893, 1972.

19 C.W. Burnham, Water and magmas: a mixing model, Geochim. Cosmochim. Acta 39, 1077-1084, 1975.
20 E. Stolper. Water in silicate glasses: an infrared spectroscopic study, Contrib. Mineral. Petrol. 81, 1-17. 1982.

21 B.O. Mysen, D. Virgo, W.J. Harrison and C.M. Scarfe. Solubility mechanisms of $\mathrm{H}_{2} \mathrm{O}$ in silicate melts at high pressures and temperatures: a Raman spectroscopic study. Am. Mineral. 65, 900-914, 1980.

22 B.O. Mysen and D. Virgo. Raman spectra and structure of fluorine- and water-bearing silicate glasses and melts. Proc. 2nd Annu. Conf. Adv. Mat. Char., Plenum Press (in press).

23 E.M. Rabinovich, On the structural role of fluorine in glass. Phys. Chem. Glasses 24, 54-56, 1983.

24 K. Rau. A. Muhlich and N. Treber. Progress in silica fibers with fluorine dopant (abstract). Topical Meeting on Optical Fiber Transmission. II, Williamsburg, Virginia. Conf. Proc.. ruCl-TuC4. 1977.

25 B.O. Mysen and D. Virgo. Structure and properties of fluorine-bearing aluminosilicate melts: the system $\mathrm{Na}_{2} \mathrm{O}-\mathrm{Al}_{2} \mathrm{O}_{3} \cdot \mathrm{SiO}_{2}-\mathrm{F}$ (submitted to Contrib. Mineral. Petrol.).

26 D.A.C. Manning. D.L. Hamilton, C.M.B. Henderson and M.J. Dempsey. The probable occurrence of interstitial $\mathrm{Al}$ in hydrous F-hearing and F-free aluminosilicate melts. Contrib. Mineral. Petrol. 75. 257-262. 1980.

27 L.N. Kogarko and L.N. Krigman. Structural position of fluorine in silicate melts (according to melting curves). Geochem. Int. 9. 34-40, 1973.

28 Y. Bottinga and D.F. Weill. The viscosity of magmatic silicate liquids: a model for calculation. Am. J. Sci. 272. $438475,1972$.

29 O.F. Tuttle and N.L. Bowen, Origin of granite in the light of experimental studies in the system $\mathrm{KAISi}{ }_{3} \mathrm{O}_{\mathrm{K}}-\mathrm{NaAlSi}_{3}$ $\left.\mathrm{O}_{8}-\mathrm{SiO}\right)_{2}-\mathrm{H}_{2}$ (). Geol. Soc. Am. Mem. 74, 1958.

30 G.C. Brown and W.S. Fyfe. The production of granitic melts during ultrametamorphism. Contrib. Mineral. Petrol. $28,310-318,1970$.

31 W.L. Huang and P.J. Wyllie. Melting reactions in the system $\mathrm{NaAlSi}_{3} \mathrm{O}_{8}-\mathrm{KAISi}_{3} \mathrm{O}_{8}-\mathrm{SiO}_{2}$ to $30 \mathrm{kbar}$, dry and with excess water. J. Geol. 83, 737-748. 1975.

32 J.B. Gill, Orogenic Andesites and Plate Tectonics. Springer-Verlag. Berlin, 1981.

33 A.J. Piwinskii. Studies of batholithic feldspars: Sicrra Nevada, California, Contrib. Mineral. Petrol. 17. 204-223. 1968.

34 W. Compston and B.W. Chappell. Sr-lsotope evolution of granitoid source rocks, in: The Farth. Its Origin. Structure and Evolution, M.W. McElhinny. ed., pp. 327..426. Academic Press. New York. N.Y.. 1979.

35 A.J.R. White and B.W. Chappell, Ultrametamorphism and granitoid genesis. Tectonophysics 43, 7-22, 1977.

36 R.H. Vernon. Restite. xenoliths and microgranitoid enclaves in granites, J. Proc. R. Soc. N.S.W. 116, 77103. 1983.

37 S.R. Jurewicz and E.B. Watson. Distribution of partial melt in a felsic system: the importance of surface energy, Contrib. Mineral. Petrol. 85. 25-29. 1984.

$38 \mathrm{H}$. Waff and J.R. Bulau, Equilibrium fluid distribution in an ultramafic partial melt under hydrostatic stress conditions, J. Geophys. Res. 84, 6109-6114, 1982. 
39 V.T. Arndt. Ultrabasic magmas and high-degree melting of the mantle. Contrib. Mineral. Petro. 64. 205-221. 1977.

40 N.H. Sleep, Segregation of magma from a mostly crystalline mush, Bull. Geol. Soc. Am. 85, 1225-1232, 1974.

41 D.L. Turcotte and J.L. Ahern. A porous flow model for magma generation in the asthenosphere. J. Geophys. Res. 83. $767-772.1978$.
42 E.H. Christiansen, D.M. Burt. M.F. Sheridan and R.T. Wilson. The petrogenesis of topaz rhyolites from the western United States. Contrib. Mineral. Petrol. 83. 1630. 1983. 